\title{
How cigarette design can affect youth initiation into smoking: Camel cigarettes 1983-93
}

\section{G Ferris Wayne, G N Connolly}

See end of article for authors' affiliations

.....................

Correspondence to: Geoffrey Wayne, 250 Washington Street, 4th Floor, Boston, MA 02108 , USA; geoffrey.wayne@state.ma.us
Context: Internal industry documents may shed light on how cigarettes are designed to promote youth smoking.

Objective: To determine changes in the design of Camel cigarettes in the period surrounding the "Smooth Character" advertising campaign and to assess the impact of these changes on youth smoking.

Data sources: Internal documents made available through the document website maintained by RJ Reynolds, manufacturer of Camel cigarettes.

Study selection: Electronic searches using keywords to identify relevant data.

Data extraction: A web based index search of documents targeting "smoothness" or "harshness" and "younger adult smokers" ("YAS") or "first usual brand younger adult smokers" ("FUBYAS") in the 10 year period surrounding the introduction of the "Smooth Character" campaign was used to identify Camel related product design research projects. A snowball methodology was used: initial documents were identified by focusing on key words, codes, researchers, committees, meetings, and gaps in overall chronology; a second set of documents was culled from these initial documents, and so on.

Data synthesis: Product design research led to the introduction of redesigned Camel cigarettes targeted to younger adult males coinciding with the "Smooth Character" campaign. Further refinements in Camel cigarettes during the following five year period continued to emphasise the smoothness of the cigarette, utilising additives and blends which reduced throat irritation but increased or retained nicotine impact.

Conclusions: Industry competition for market share among younger adult smokers may have contributed to the reversal of a decline in youth smoking rates during the late 1980s through development of products which were more appealing to youth smokers and which aided in initiation by reducing harshness and irritation.
R Reynolds (RJR) was the leading US cigarette manufacturer throughout the 1960s and 1970s. However, the company's leading brand Winston experienced sales declines beginning as early as 1969 and continuing throughout the 1970s and early 1980s. RJR recognised as underlying this decline a shift in the preferences of younger smokers away from Winston and other RJR brands. ${ }^{1}$ During this same time period, Philip Morris grew from $9.5 \%$ to $31 \%$ of the overall market. ${ }^{2}$ This growth was due largely to the success of Marlboro, which had been repositioned during the 1950s and increased steadily in share beginning in 1966. By 1980 Marlboro had become the most popular cigarette among younger smokers, with approximately $40 \%$ of the 18 year old market. ${ }^{3}$ RJR was faced with not only a challenge for market leadership but also an aging consumer base.

A strategic analysis from January 1981 shows that RJR identified product design issues as a primary reason for this market shift.

\footnotetext{
"During the 1970s, RJR products and Philip Morris products diverged from each other in product and hence in smoke delivery characteristics. Because RJR's focus was satisfying the full flavor smoker, our products remained high in tar and nicotine with a stronger and harsher smoke delivery and more tobacco taste. In the meantime, PM products, decreasing in tar and nicotine delivery, gradually converted to a product which was milder, less harsh, and with less tobacco taste." ${ }^{4}$
}

RJR instituted design changes in 1980 and 1981 that were intended to close this product gap, "as key factors contributing to product weakness were discovered in tar, nicotine, menthol, and moisture levels". ${ }^{4}$ Camel was repositioned to become the contemporary younger adult smoker (YAS) brand, taking direct aim at Marlboro, and its development was made one of RJR's top priorities. ${ }^{5}$ Marketing and product research initiatives directly targeting the YAS market were launched in 1983, influencing changes in Camel products through the remainder of the decade.

Youth smoking prevalence rates significantly increased during the early 1990s. Between 1991 and 1997, 30 day adolescent prevalence rates rose from $28 \%$ to $36 \%{ }^{6}$ Although initiation rates (those who have ever tried smoking) continued to decrease throughout the 1980s and early 1990s, prevalence of daily cigarette smoking increased at all grade levels among the classes of 1989, 1990, and 1991.

Prior analyses have linked this increase in prevalence to marketing and advertising. ${ }^{89}$ The introduction of the Camel "Smooth Character" marketing campaign in 1988 may have influenced this rate increase. Youth market share increased more significantly for Camel than for other popular youth brands (Marlboro, Newport) during this period. ${ }^{8}$ Joe Camel (Smooth Character) advertisements were also the most popular advertisements named in a 1993 adolescent survey. ${ }^{10}$ However, internal industry studies suggest that marketing campaigns, though successful in initiating occasional use, do not translate to increased market share for products that do not appeal to consumers. An analysis of the young adult marketed brand Magna is instructive: in this case, "[t]he brand successfully generates higher levels of occasional use but these smokers are as of yet unwilling to adopt MAGNA as their

Abbreviations: DAP, diammonium phosphate, FTC, Federal Trade Commission; FUBYAS, first usual brand younger adult smoker; RJR, RJ Reynolds; TSB, two stage blend; YAS, younger adult smoker 


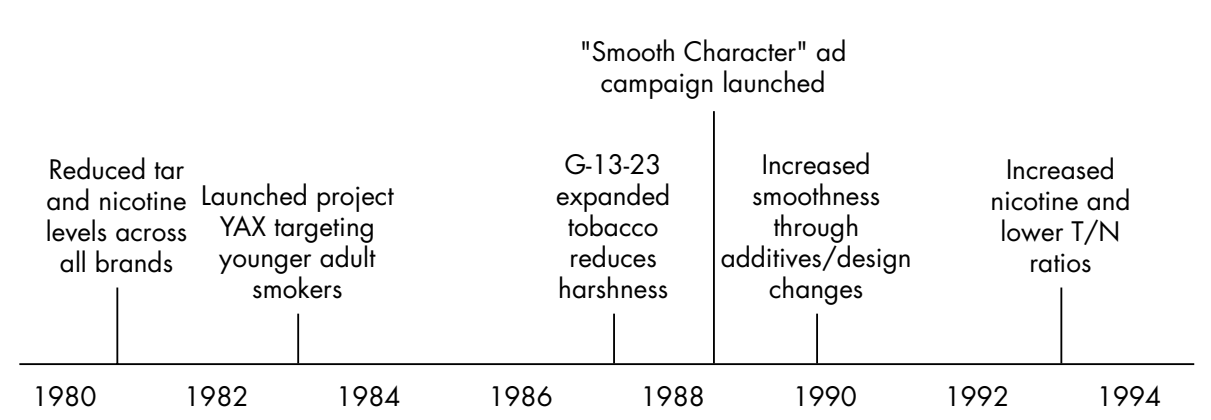

Figure 1 Time line of Camel design changes.

usual brand". This is attributed in part to "[n]egative product perceptions lingering from trial prior to product improvement". ${ }^{11}$

Transformation of Camel cigarettes into a brand favoured by youth may have required product changes supporting increased initiation and uptake. Product changes would be anticipated to coincide with introduction of the Smooth Character advertising campaign. The research presented in this paper was prompted by the question of what product design changes, if any, may have influenced the uptake of youth smoking prevalence and increased brand market share for Camel in the period surrounding this campaign. Internal industry documents were used to gain insight into the effects of product design changes on Camel cigarettes and to understand the possible impact on youth smoking.

\section{METHODS}

This study examines design changes in Camel cigarettes for the five years before and after the introduction of the Smooth Character advertising campaign (1988). A preliminary, web based (www.rjrtdocs.com) index search of documents targeting "smoothness" or "harshness" and "younger adult smokers" ("YAS") or "first usual brand younger adult smoker" ("FUBYAS") provided an outline set of Camel related projects, including projects YAX, TSB, XG, and ZX (all grouped in the years preceding the campaign) and projects RU, SS, and EW (after the campaign). A snowball methodology was utilised: documents were targeted using relevant indexed keywords (for example, smoothness, harshness, perception, youth, product, design, blend, consumer, etc) and documents related to the projects identified above. The initial documents provided a secondary list of names of researchers, management, committees, and weekly and monthly committee meetings. Untitled documents were located using the identifying Bates number. Documents were reviewed for keywords, codes, or projects. Finally, the relevant documents were ordered chronologically and a search was performed for all Camel related documents in those month intervals that appeared as gaps in the overall chronology. The final set of relevant documents catalogued for this study number approximately 1000. Two researchers reviewed and analysed this final study set.

\section{RESULTS}

Figure 1 shows a time line of Camel design changes.

\section{Importance of FUBYAS}

RJR underscored the importance of the YAS market for the future of the company in a 1983 analysis: "Appeal to younger adults is critical for long term brand growth. Brands that attract 18-24 year olds grow in total. Brands losing appeal among younger adults decline in total." ${ }^{12}$ Among the YAS segment the most important group was the YAS choosing a first regular brand, called the "first usual brand younger adult smoker" (FUBYAS). In 1974, RJR had turned its attention to the process by which younger smokers choose an initial brand for regular use with a memorandum titled "What causes smokers to select their first brand of cigarette?". The memo observed that more than half of all male smokers begin smoking before the age of 18 years, and 95\% begin before the age of 25. Selection of a first brand for these younger smokers gravitated towards market dominant brands such as Marlboro and Kool, perpetuating share growth. The origins of this brand dominance appeared to be based on "...influential young smokers (perhaps relatively few) [who] have made brand selections based on product characteristics or advertising and promotion communication." ${ }^{13}$ These observations, suggesting that successful appeal to first time smokers will in part reflect product characteristics, anticipated RJR's decline in market share throughout the 1970s due to products that failed to appeal to younger smokers.

Further research by RJR in the late 1980s supports these findings: "All major brands in the cigarette market in the last 50 years successfully attracted FUBYAS" $^{\prime 3}$ (see fig 2). A successful first brand produces dramatic growth through its ability to attract young smokers who remain loyal to the brand over time and significantly increase consumption as they age.
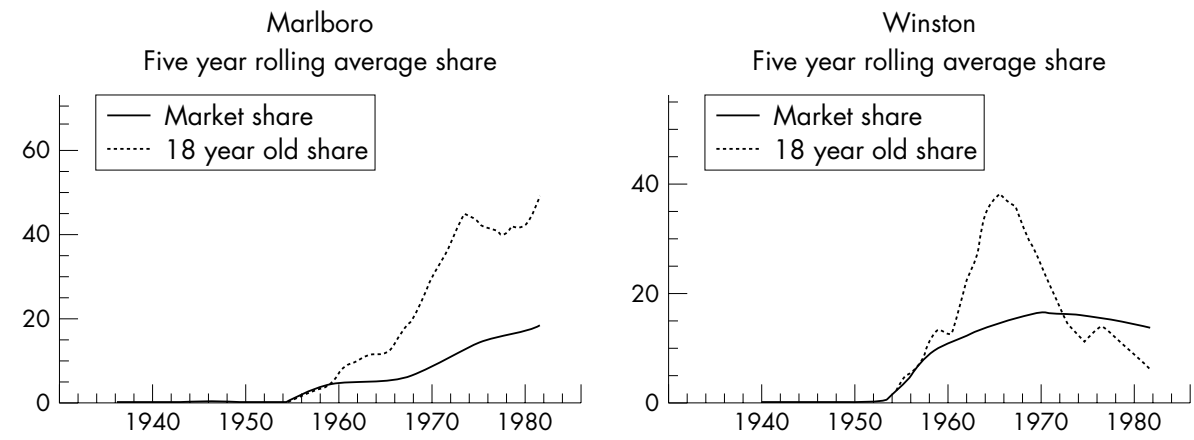

Figure 2 Pattern set by 18 year olds (dotted line) determines the trend in overall market share (solid line). Marlboro gains overall share while Winston's decline follows losses in 18 year old segment. Source: Younger adult smokers. February 8, 1988. Bates No. 506563374-3437. 
This was most famously true in the case of Marlboro: "Marlboro's dynamic growth is due solely to its gains as a successful first brand which significantly overcomes the net switching losses that the brand incurs." ${ }^{14}$ Other successful major brands were shown to have followed a similar pattern, including Pall Mall, Winston, Kool, and Newport. "There have only been five major cigarette brands which benefitted from the FUB dynamic during the past 50 yers [sic]. In fact, FUBYAS played some role in creating all the major brands that have developed in the business.." ${ }^{15}$ In each of these cases market dominance was first established among YAS, which then translated to dominance in the greater market. As these brands lost touch with the YAS market, their share gradually diminished. ${ }^{3}$

\section{Designing a cigarette for the first time smoker}

Camel product development experienced a significant shift on the basis of these analyses. In 1970, a confidential memo rejects the idea of developing a milder Camel product both because "[a] 'mild' product is antithetical to the CAMEL image and heritage" and because "[w]e are not aware of any major brands with predominantly male franchises that are growing through any advertised appeal other than taste (witness Marlboro and Kool)". ${ }^{16}$

By 1983, the issue had been revisited with focus on identifying product characteristics that would appeal to YAS and first time smokers.

RJR determined that the most important physical characteristic of the younger adult brand was its smoothness or mildness. Pall Mall, for example, “. . . featured extra mildness through extra length ..." as the first $85 \mathrm{~mm}$ cigarette. Winston then replaced Pall Mall as the first filter cigarette, " . . .with mildness advantage versus non-filter cigarettes". Marlboro “... offered [a] product with substantially milder delivery than Winston". Newport, as the first menthol cigarette targeted toward the younger adult market, offered a “ . . milder product than Kool and benefited from the older images of Kool and Salem". ${ }^{14}$ A 1973 internal memo titled "Some thoughts about a new brand of cigarettes for the youth market" identified the need to provide a cigarette "as bland and free of obvious negatives as possible ${ }^{\prime \prime}{ }^{17}$

RJR research of a product that would successfully appeal to the first time smoker centred on a cigarette prototype coded "XG". According to an August 1985 summary of the product development plan:

\section{"Two key areas identified for improvement were smooth- ness and sweetness delivery. Smoothness is an identified opportunity area for improvement versus Marlboro, and sweetness can impart a different delivery taste dimension which younger adult smokers may be receptive to, as evidenced by their taste wants in other product areas." ${ }^{\prime 18}$}

A "Project XG ideation session" provided strategies for attracting the novice smoker. Among them were increased "hit/kick" (that is, nicotine impact) through the use of organic acids, special tobaccos, D-nicotine (rather than L-nicotine), "suppression of trigeminal nerves that are receptive to hot/harshness", and using caffeine as a "substitute for nicotine kick" in a non-tobacco (alfalfa) cigarette. Additives were suggested to enhance mouth sensations in the manner of carbonisation of colas. Proposed increases in smoothness included manipulation of $\mathrm{pH}$; filter additives which selectively remove nicotine; use of a humectant coating to close off nerves; or other additives which alter taste buds for different taste perceptions. Suggested flavours included "taste enhancers that increase salivation and smoothness perceptions". ${ }^{19}$

Another aspect of Camel development focused on improvements in harshness. A company wide "harshness workshop" was convened in December 1985 as a means for "accelerating the process for making improvements in this area". ${ }^{20}$

"Historically, RJR products have been perceived and rated as being harsher than their respective Philip Morris counterparts ... Given the corporate emphasis placed on competitive younger adults as being a source of new and future business, it has been recognized and agreed upon that significant improvements in the harshness ratings of WINSTON King, WINSTON Lights, CAMEL Filter, and CAMEL Lights must be realized in order to increase acceptance among the aforementioned smoker group. ${ }^{\prime 20}$

Later, introduction of Ultralight and "smooth" Camel extension brands were considered as a strategy for altering overall perceptions of the Camel brand and providing "leveragable points of difference versus Marlboro and which are consistent with CAMEL's 'smooth' positioning". ${ }^{21}$ A partial list of research projects introducing new product concepts for targeting YAS smokers is provided in table 1.

Product analysis also focused on first time smokers by differentiating the wants and perceptions of different subgroups. For example, at the beginning of 1988 consumer perception testing found Marlboro superior to Camel on overall acceptance. $^{22}$ However, breaking the product perception testing into subgroups, the study found that Camel was perceived by 18-20 year olds as significantly milder and having more tobacco taste than was found by $21-24$ year olds. Product perceptions thus appeared to differ between age groups. In addition: "These results indicate that attribute importance may be different for 18-20 year olds relative to 21-24 year olds."'22 As a long term goal, it was noted that both age subgroups desired the same basic product wants including "strength, smoothness and less harshness". ${ }^{22}$

\section{Developing a cigarette for the youth market}

YAS prototypes were developed by identifying product design elements that addressed the issues of smoothness, harshness, and mildness while maintaining nicotine delivery. A brainstorming session identified solvents, leaf/blends, tobacco

Table 1 Examples of projects introducing "younger adult smoker" (YAS) product concepts

\begin{tabular}{|c|c|c|}
\hline Project name & Goal & Research \\
\hline$X G$ & Overall product superiority to Marlboro among $18-24$ year old males & $\begin{array}{l}\text { Areas identified for improvement were smoothness and } \\
\text { sweetness delivery }\end{array}$ \\
\hline TSB (two-stage blend) & $\begin{array}{l}\text { Provide "hidden" new/unconventional technology allowing } \\
\text { manipulation of impact/perception }\end{array}$ & $\begin{array}{l}\text { Separate blends at front and back end of cigarette; high } \\
\text { initial impact with less harshness, "taste burnout" }\end{array}$ \\
\hline $\mathrm{FC} / \mathrm{QQ}$ & $\begin{array}{l}\text { Smooth, satisfying tobacco taste and a distinctly masculine/ } \\
\text { individualistic brand image }\end{array}$ & Wide circumference cigarette (Camel Wides) \\
\hline RU & Milder, smoother, lighter Camel Lights & $\begin{array}{l}\text { Used G7-25 (DAP) reconstituted blend and "smoothness } \\
\text { enhanced top dressing" (Camel Special Lights) }\end{array}$ \\
\hline FAT (fresh after taste) & Fresh aftertaste to appeal to young/ new smokers & "Minty" taste achieved through subliminal levels of menthol \\
\hline
\end{tabular}


Table 2 Examples of younger adult targeted product design features

\begin{tabular}{|c|c|c|c|}
\hline Design feature & Approach & Description & Results \\
\hline Tobacco blend & Two stage blend & $\begin{array}{l}\text { Separate blends used at front and back end of the } \\
\text { cigarette }\end{array}$ & Allowed strength in initial puffs, smoothness in later puffs \\
\hline Puffed tobacco & G13-23 & Puffed tobacco filler & Improved mouth sensation and throat scratch \\
\hline Humectant & Glystar & Replacement for glycerin/ propylene glycol & Increased smoothness \\
\hline Flavourant & $\begin{array}{l}\text { "Combination top } \\
\text { dressing" }\end{array}$ & Chocolate, vanillin, licorice, and "tobacco enhancer" & Significant appeal among 18-24 year old smokers \\
\hline Filter & Carbowax & Filter additive & $\begin{array}{l}\text { Reduced harshness, mouth sensation, throat dryness, } \\
\text { bitterness }\end{array}$ \\
\hline
\end{tabular}

processing, and cigarette construction as key design issues, including such possible areas of investigation as perforation type and placement, cigarette paper and filter materials, and modifications of burn characteristics and blend components. "It was generally agreed that processing offers the greatest potential for effectively reducing or eliminating the harshness/ irritation problem." ${ }^{20}$ Processing issues included modification of the base reconstituted blend, use of ammoniated and denicotinised tobacco, use of puffed tobacco, and experimentation with new tobacco types and casings. ${ }^{23} \mathrm{~A}$ partial list of product design elements used to affect smoothness/harshness is shown in table 2 .

One flavourant developed to increase smoothness perceptions for project XG appears to have demonstrated significant results: a combination top dressing consisting of chocolate, vanillin, licorice, and "tobacco enhancer flavor". A personal memo from November 22 to the developer of the flavourant notes:

"I would like to express my sincere appreciation for the exciting flavoring work you have done on Project XG. The chocolate/ vanillin/licorice/ tobacco enhancer is undoubtedly one of the most exciting and promising flavorants that has been developed during the last several years... As you know, this flavorant appears to have significant appeal among the 18-24 year old smoker group and this is obviously the group that we desperately are after." 24
Among the product characteristics associated with this flavourant in consumer focus groups were "sweet taste", "different", "tingling feeling", and "not as rough". ${ }^{25}$

A series of unconventional prototypes were developed using a technology known as TSB, or two stage blend, in which separate leaf blend segments with varying nicotine content or tobacco density were placed at the front and back ends of the cigarette. This gave the manufacturer control over tar and nicotine delivery in both the early and later puffs on the cigarette. ${ }^{26}$ TSB offered significant advantages over the conventional cigarette in achieving a smoother product because it did not need to rely on a reduction in nicotine to achieve the desired result. In addition, while TSB enabled manufacturers to alter product perceptions in ways unavailable using conventional cigarette technology, it also provided the advantage of " . . a 'hidden' technology in that products fully utilizing this technology can be prepared and marketed as typical cigarettes". ${ }^{27}$

A partial list of developed Camel prototypes is provided in table 3. Successful prototypes addressed issues of smoothness/ harshness while maintaining or increasing strength and nicotine impact. Among the prototypes developed were modified Camel and Winston blends with high tar/nicotine ratio, increased moisture levels, modifications to the filter, and use of additives. ${ }^{28}{ }^{29}$ An experimental reconstituted tobacco resulted in prototypes that were "more like Marlboro in delivery . . providing a product that is smoother and with more tobacco taste simultaneously" ${ }^{18}$ Camel Lights research

Table 3 Examples of Camel prototypes

\begin{tabular}{|c|c|c|c|}
\hline Project/prototype & Design changes & Effects & Outcome \\
\hline ZX (12 mg) & $\begin{array}{l}\text { Strong tobacco on fire end } \\
\text { Smoother tobacco on filter end } \\
\text { Reduced differential between ends }\end{array}$ & $\begin{array}{l}\text { Increased strength } \\
\text { Increased smoothness } \\
\text { Reduced harshness }\end{array}$ & $\begin{array}{l}\text { Matched Marlboro with increased smoothness at } \\
\text { end of cigarette }\end{array}$ \\
\hline СТ-790-А & $\begin{array}{l}\text { Experimental G-7 (without G-9) } \\
\text { Experimental G-13 (puffed tobacco without } \\
\text { top dressing) } \\
\text { No air dilution } \\
\text { No denicotinised tobacco (KDN) }\end{array}$ & $\begin{array}{l}\text { Increased smoothness } \\
\text { Increased smoothness } \\
\text { Increased strength } \\
\text { Increased strength }\end{array}$ & $\begin{array}{l}\text { Smoother product but too harsh; recommend } \\
\text { further development using prototype as basis }\end{array}$ \\
\hline CT-1559-B & $\begin{array}{l}\text { Lower nicotine burley } \\
\text { Low nicotine flue cured tobacco } \\
\text { G-7-4 (new reconstituted sheet) } \\
\text { Increased humectant } \\
\text { New top dressing } \\
\text { Reduced draft/reduced draw resistance }\end{array}$ & $\begin{array}{l}\text { Increased smoothness } \\
\text { Less harsh, smoother } \\
\text { Improved acceptance } \\
\text { Increased smoothness } \\
\text { Increased smoothness; } \\
\text { "Marlboro-Like" } \\
\text { Increase strength without harshness }\end{array}$ & $\begin{array}{l}\text { Implemented in February } 1989 \text { as Camel Lights; } \\
\text { rated parity to Marlboro on acceptance }\end{array}$ \\
\hline CT-1582 A/D & $\begin{array}{l}\text { No burley casing } \\
\text { Low pack moisture } \\
4 \% \text { Glystar (Hystar/glycerin) } \\
\text { K22 (Heat treated burley, no KDN) } \\
\text { Decreased dilution/ increased draft }\end{array}$ & $\begin{array}{l}\text { Decreased harshness } \\
\text { Increased strength } \\
\text { Decreased harshness } \\
\text { Decreased harshness } \\
\text { Increased tobacco taste }\end{array}$ & $\begin{array}{l}\text { Preliminary testing found increased smoothness } \\
\text { among } 18-20 \text { year olds; manufacturing prototype } \\
\text { too harsh, less smooth }\end{array}$ \\
\hline
\end{tabular}


Table 4 Federal Trade Commission tar/nicotine levels (T/N ratio in parentheses)

\begin{tabular}{lllll}
\hline Year & Camel Filter & Camel HP & Camel Light & Camel HP Light \\
\hline 1982 & $15 / 1.0(15)$ & - & $8 / 0.7(12)$ & $8 / 0.7(11)$ \\
1986 & $15 / 1.0(15)$ & $16 / 1.0(16)$ & $9 / 0.6(15)$ & $10 / 0.6(17)$ \\
1988 & $16 / 1.0(16)$ & $17 / 1.1(15)$ & $9 / 0.6(15)$ & $10 / 0.6(17)$ \\
1989 & $15 / 1.0(15)$ & $17 / 1.0(17)$ & $9 / 0.7(13)$ & $9 / 0.6(15)$ \\
1991 & $15 / 1.1(14)$ & $17 / 1.2(14)$ & $11 / 0.8(14)$ & $9 / 0.7(13)$ \\
1992 & $14 / 1.0(14)$ & $17 / 1.2(14)$ & $11 / 0.8(14)$ & $9 / 0.7(13)$ \\
1993 & $17 / 1.2(14)$ & $18 / 1.3(14)$ & $11 / 0.8(14)$ & $11 / 0.8(14)$ \\
1994 & $18 / 1.4(13)$ & $17 / 1.3(13)$ & $11 / 0.9(12)$ & $11 / 0.9(12)$ \\
\hline \multicolumn{2}{r}{ Source: FTC reports on "Tar", nicotine, and carbon monoxide of smoke. } \\
\end{tabular}

"to enhance smoothness and mildness" was conducted utilising a material called Carbowax that reduced "mouth sensation" and harshness without apparent impact on tobacco taste. ${ }^{30}$ A reconstituted blend, G7-25, developed under project SS (Supersmooth) with diammonium phosphate (DAP) was found to be smoother and less harsh than other G7 (reconstituted tobacco) types.

\section{Bringing YAS design changes into the marketplace}

Project research and prototype development led to a series of YAS targeted design changes in Camel cigarettes. The first of these was implementation of G-13-23, a new puffed tobacco eventually adopted across all RJR brands that offered "positive shifts in attributes of aftertaste, bitterness, mouth sensation, and throat scratch . ..". ${ }^{31}$ Implementation of G-13-23 in late 1986 appears to have at least partially addressed the harshness deficiency characterising RJR products through 1985. Attribute ratings for Camel Filter, Filter Light, and Hard Pack show a decrease in harshness attribute ratings from 1986 to 1987, after implementation of the new puffed tobacco. ${ }^{22}$ YAS consumer testing indicated a subsequent shift from inferiority to parity status versus Marlboro by mid 1987. This shift may also have been due in part to a simultaneous decrease in Marlboro consumer ratings. ${ }^{24}$ Successfully addressing Camel's negative harshness attributes appears to have been the first step in positioning the brand toward the YAS market.

In 1989 and early 1990 product changes were implemented across Camel brand styles following extensive YAS consumer testing. For Camel Filter these changes included use of a new humectant (Glystar), reduced circumference, and increased tobacco density. ${ }^{32}{ }^{33}$ Camel Lights implemented a new reconstituted sheet with a lower level of nicotine extract, a new "topdressing", increased humectant, and reduced filter draft. ${ }^{34-36}$ Changes in the Camel Hard Pack styles included alterations of blends, top dressings, humectants, cigarette papers, cuts-perinch of tobacco, and changes to the filter. ${ }^{37}{ }^{38}$ These product changes increased smoothness perceptions while in most cases showing no demonstrable impact on attributes of strength (nicotine impact) and taste. In August of 1992, Camel Filter and HP products were consolidated with the HP configuration implemented across both styles. Product testing found that "on a directional basis, the [HP] product was rated less strong, had less tobacco taste, more smoothness/mildness among soft pack smokers on a blind basis" ${ }^{39}$

Recorded shifts in measured tar and nicotine levels by the Federal Trade Commission (FTC) confirm the product design changes described in tobacco industry documents for Camel Filter and Camel Hard Pack between 1989 and 1991 and for Camel Filter after 1992, as well as product design changes for Camel Light and Hard Pack Light between 1988 and 1989, and again between 1989 and 1991 (table 4) The product design changes are not accompanied by reduced levels of nicotine but proportionally large increases, from 1.0 to $1.4 \mathrm{mg}$ in Camel Filter, from 1.0 to $1.3 \mathrm{mg}$ in Camel Hard Pack, and from 0.6 to $0.9 \mathrm{mg}$ in Camel Lights and Hard Pack Lights. The trend for both tar levels and nicotine levels was upward between 1989 and 1994, while simultaneously tar/nicotine ratios were reduced. The reduction in the tar/nicotine ratios indicates that for a given amount of cigarette smoke, the amount of nicotine increases relative to the total tar amount or more nicotine per unit of tar. This suggests that Camel product design changes increased the potential for addiction through increases in nicotine delivery.

Although increased nicotine delivery is typically associated with increased throat impact and irritation, product attribute measures for Camel brand styles between 1988 and 1991 suggest that increases in nicotine were offset by product changes targeting smoothness and harshness. Design changes instituted between 1987 and 1993 consistently focused on designing cigarettes that were milder and easier to smoke. The introduction of the Camel "Smooth Moves" advertising campaign in late 1988 also targeted negative consumer perceptions and may have altered product perceptions ${ }^{40}$ Coupled with product improvements in smoothness/harshness, the result was Camel cigarettes that were easier to smoke even as they delivered more nicotine.

Two Camel YAS extension projects were successfully introduced to market during this period: Camel Wides (project QQ) and Camel Special Lights (project RU). Both products arose directly out of smoothness research. The development of a wider circumference cigarette was begun in 1987-88 under project FC and later reborn under project QQ. ${ }^{41}$ A successful smoother prototype was introduced for market testing in 1991 which found: "Communication of the smoothness product benefit has the greatest impact on trial interest" and "[t]he overwhelming majority of smokers (89\%) felt the QQ product was as good or better than they expected prior to trial" ${ }^{42}$ This brand extension was released nationally as Camel Wides in 1992. Project RU, “a milder, smoother, lighter tasting" Camel Lights product, developed a prototype identified as ideal on harshness and tobacco taste using the G7-25 (DAP) reconstituted blend and a "smoothness enhanced top dressing". ${ }^{43}$ After introduction into the market in April 1993, Camel Special Lights were modified with reduced G7-25, removal of $\mathrm{KDN}$, and utilisation of "steam flotation optimization". ${ }^{44}$

\section{Effects of the redesigned Camel on youth smoking}

Product changes, coupled with the targeted Smooth Character campaign, were successful in altering product perceptions of Camel products. Between 1989 and 1990 (after introduction of product changes), a product perception study recorded a decrease in percentage of 18-24 year old male respondents describing Camel as "harsh/rough" from $25.8 \%$ to $23.1 \%$, while the percentage responding "smooth" increased from $15.8 \%$ to $20.9 \% .^{45}$ Nonetheless, strong ingoing perceptions of strength and harshness associated with the Camel brand continued, as shown in consumer testing:

"Identified product has ingoing perceptions/ expectations that shorten the amount of time necessary to form an opinion. It may take only a few puffs/cigarettes to confirm ingoing expectations, which is one reason 


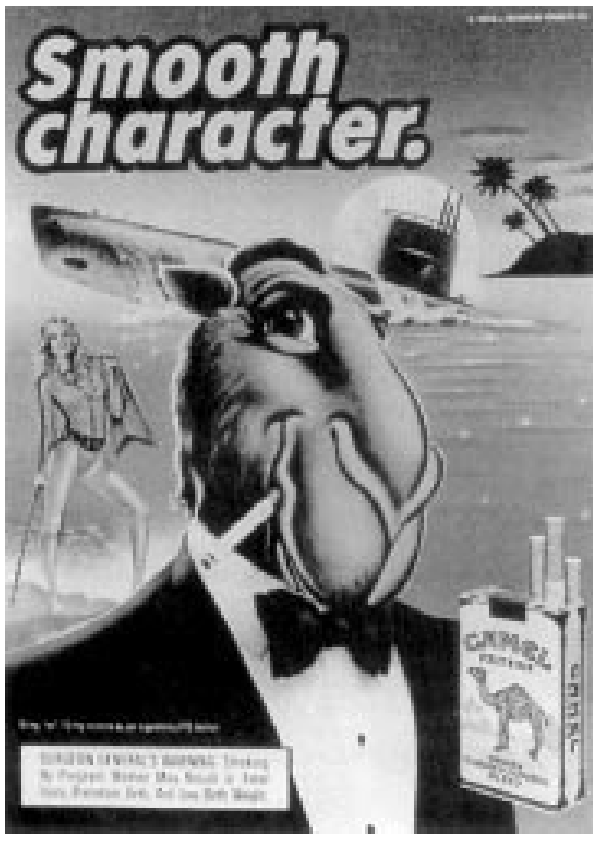

Figure 3 The Camel "Smooth Character" advertisement.

why ingoing perceptions effect [sic] identified product ratings. As a result, any differences in taste performance ... must be noticeable during the first few puffs/ cigarettes; otherwise, they will be swayed more by ingoing expectations." ${ }^{46}$

Product development did not fully offset expectations because the product tested was perceived as having "more strength/tobacco taste than it actually has" and "more harsh/ less mild taste than it actually has". ${ }^{46}$

The Smooth Character advertising theme directly targeted a new set of product expectations for the redesigned Camel cigarette (fig 3). However, YAS consumer testing continued to show Camel brands at a disadvantage to competing Marlboro products. Successful movement in Camel brands towards smoothness/reduced harshness appears to have been paced by developments in competing Marlboro products. RJR's YAS consumer testing of Marlboro HP and HP Lights between 1986 and 1992 show increases in smoothness and decreases in harshness. ${ }^{22}{ }^{39}$ Reports from 1990 and 1991 record continued smoothness/mildness taste deficiencies for Camel products in comparison with Marlboro counterparts. ${ }^{47} 48$ Although RJR had successfully altered product perception of Camel, the changing marketplace necessitated continued redesign of the product along with new style introductions through the early 1990s to increase ease of use while maintaining strength and impact.

Before initiation of the Smooth Character advertising campaign in late 1988 Camel demonstrated share growth among $18-24$ year olds, moving progressively from $2.5 \%$ of market in 1987 , to $4.0 \%$ in 1988 , to $4.4 \%$ in 1989 , to $6.1 \%$ in $1990 .{ }^{49}$ The slowest growth appears from 1988 to 1989 during a period with no apparent design changes. Figure 4 illustrates graphically the development of Camel brand share in the late 1980s as its primary adult age group shifts from 30 year olds (in 1985-86) to 18 year olds (in 1988). ${ }^{50}$ Again, the most significant share movement appears between 1987 and 1988 and between 1989 and 1990. Among 18 year olds, Camel's share of the market grew from 2.5\% to $14 \%$ between 1985 and 1993, with market share trending increasingly downward by age. By 1993 Camel had been successfully transformed into a YAS brand.

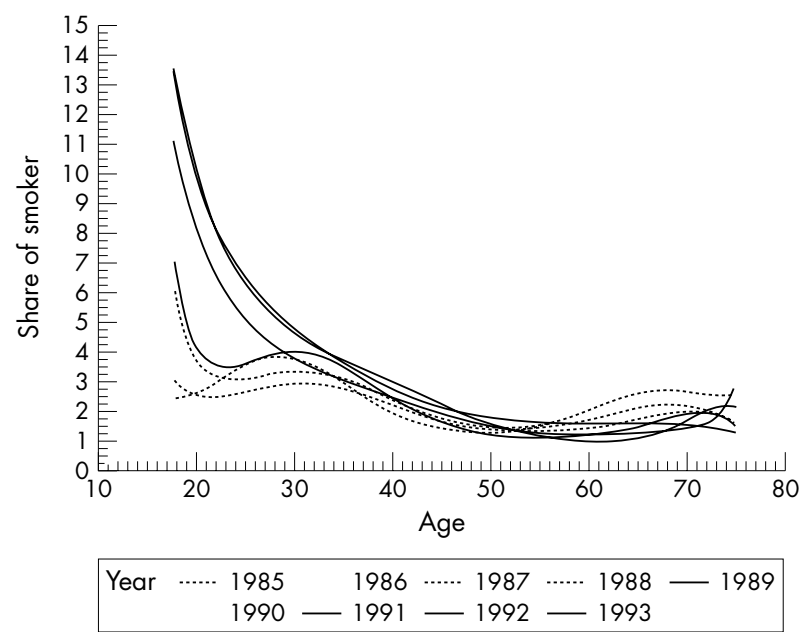

Figure 4 Camel's share by age 1985-93. Camel's adult market share increase is driven by the youngest (18 year old) cohort. Source: RC Pasterczyk, Camel (Ex Nf) Sos by age, year, 21 March 1994. Bates No. $509684799-4803$.

\section{DISCUSSION}

In the late 1980s Camel became one of three leading brands, along with Marlboro and Newport, which today account for more than $80 \%$ of adolescent smoking. ${ }^{67}{ }^{51}$ Before 1987, failure to develop a more appealing product limited Camel's effectiveness in gaining YAS market share. Product design changes toward a smoother, less harsh cigarette for the YAS market may have been a factor driving Camel market gains in 1987 (with the implementation of G-13-23) and again in late 1989 and early 1990 (with implementation of Glystar, G7-4, and other changes). The effects of these changes on the youth market may also have been multiplied by consequent changes in other youth brands mirroring the Camel smoothness and harshness improvements.

Internal documents suggest a strong link between the effects of product design and market share among YAS. According to internal industry research, all brands successful among YAS (including Marlboro and Newport) first demonstrated increased product smoothness or mildness. ${ }^{14}$ Camel's success among YAS in the late 1980s followed product design changes affecting the brand's smoothness and harshness attributes, which coincided with introduction of the "Smooth Character" (Joe Camel) advertising campaign. Nicotine levels were also increased during this time period. Design changes were generated by use of additives in filter and casing; processing and treating of tobacco and tobacco sheet; and alteration of blends, paper, circumference, density, and air dilution.

Trends in adolescent smoking shifted during the period following the redesign of Camel as a YAS cigarette, as a decline in smoking prevalence among adolescents during the late 1970s and early 1980s appears to have halted in the late 1980s and subsequently reversed, particularly among adolescent males. ${ }^{52}$ One factor that contributed to the success of Camel among adolescents during this period was an increase in advertising spending from $\$ 27$ million to $\$ 43$ million between 1989 and 1993. ${ }^{6}$ Promotions, give aways, and advertising influence the onset of smoking and continued use among youth. ${ }^{810}$ Youth are more likely than adults to be influenced by advertising. ${ }^{9}$

Product design changes which make cigarettes more palatable, easier to smoke, or more addictive are also likely to encourage greater uptake of smoking. Although one cannot prove direct causality, one can surmise that the reversal in declining youth smoking trends during the 1990s was influenced by the shift in product characteristics making cigarettes smoother and milder while increasing nicotine levels 


\section{What this paper adds}

Prior analyses have linked the rise in youth smoking prevalence during the early 1990s to increases in tobacco industry advertising and promotional spending. However, no studies have examined the influence of product design changes on youth smoking initiation and uptake.

Internal tobacco industry documents suggest that product changes that make cigarettes more palatable, easier to smoke, and more addictive, can act in coordination with advertising and promotions targeting youth, shaping product perceptions and promoting initiation. Work must be done to monitor product changes as well as assess advertising and promotional influences as part of future efforts to address youth smoking.

among brands smoked by youth. Product changes act in coordination with advertising and promotions targeting youth, by shaping product perceptions and promoting initiation. Continued work must be done to monitor product changes and assess advertising and promotional influences. Allowing the tobacco industry to target young smokers and tailor products to youth preferences will increase the likelihood of youth smoking uptake, with significant public health consequences.

\section{ACKNOWLEDGEMENTS}

Funded by a grant from the National Cancer Institute, CA87477-02 "The Design and Characterization of Cigarettes".

\section{Authors' affiliations}

G F Wayne, G N Connolly, 250 Washington Street, 4th Floor, Boston, MA 02108, USA

\section{REFERENCES}

RJ Reynolds. Winston historical review: 1954-1985. RJR Tobacco Company. 1985. Bates No. 505221872 -1874. All RJR Tobacco Company documents cited here can be found at www rirtdocs.com.

2 RJ Reynolds. Historical perspective. RJR Tobacco Company. 1986. Bates No: 505650528-0550.

3 RJ Reynolds. Marlboro analysis. RJR Tobacco Company. 1988. Bates No: $507182205-2294$

4 Gemma JL. 1981 Strategic analysis-product. RJR Tobacco Company. January 15, 1981. Bates No: 501781090-1102.

5 RJ Reynolds. 1984 established brand strategies core issue market share growth. RJR Tobacco Company. June 1983. Bates No: 505490365-0369.

6 Jacobson PD, Lantz PM, Warner KE, et al. Combating teen smoking: research and policy strategies. 2001. Ann Arbor: University of Michigan Press.

7 Johnston LD, O'Malley PM, Bachman JG. Smoking, drinking, and illicit drug use among American secondary school students, and young adults, 1975-1992: volume II, college students and young adults. 1992. Bethesda, Maryland: US Department of Health and Human Services, Public Health Service, National Institutes of Health, National Institute on Drug Abuse. (NIH Publication No. 93-3481.)

8 Pierce JP, Gilpin E, Burns DM, et al. Does tobacco advertising target young people to start smoking? Evidence for California. JAMA $1991 \cdot 266: 3154-8$

9 Cummings KM, Hyland A, Pechacek TF, et al. Comparison of recent trends in adolescent and adult cigarette smoking behavior and brand preferences. Tobacco Control 1997;6(suppl 2):S31-7

10 Pierce JP, Choi WS, Gilpin EA, et al. Tobacco industry promotion of cigarettes and adolescent smoking. JAMA 1998:279:511-15.

11 RJ Reynolds. Magna repositioning assessment: management summary. RJR Tobacco Company. May 15, 1991 . Bates No: 509148342-8363.

12 RJ Reynolds. YAX/TSB project briefing. RJR Tobacco Company. May 15, 1991. Bates No: 503795865-5885.

13 Tredennick DW. Memo in answer to the question: "What causes smokers to select their first brand of cigarette?" RJR Tobacco Company. July 3, 1974. Bates No: 501285458-5467

14 RJ Reynolds. Project XG brand review: July 9, 1984. RJR Tobacco Company. July 9, 1984. Bates No: 502761453-2142.

15 RJ Reynolds. Younger adult smokers. RJR Tobacco Company. February 8, 1988. Bates No: 506563374-3437

16 Watson JO. Project CT. RJR Tobacco Company. November 30, 1970. Bates No: 501325960-5961.

17 Teague CE. Research planning memorandum on some thoughts about a new brand of cigarettes for the youth market. RJR Tobacco Company. February 2, 1973. Bates No: 505101981-1992.
18 Gemma JL. Results of MDM committee meeting - August 13, 1985, RJR Tobacco Company. August 16, 1985. Bates No: $505520121-0126$.

19 RJ Reynolds. Project XG. RJR Tobacco Company. March 24, 1986. Bates No: $505621142-1146$

20 McCarthy RF. Harshness workshop. RJR Tobacco Company. December 10, 1985. Bates No: 507166417-6420.

21 RJ Reynolds. Brand R\&D 1990 - Non menthol product development plan (total Camel and full flavor low tar). RJR Tobacco Company. April 18, 1990. Bates No: 508238801-8830.

22 RJ Reynolds. Camel filter product development direction reassessment. RJR Tobacco Company. January 1988. Bates No: $506561770-1792$.

23 RJ Reynolds. Brands R\&D Product improvement status monthly report March 25, 1986. RJR Tobacco Company. March 25, 1986. Bates No: $505496611-6620$

24 Willard RL. Memo re: flavoring work on Project XG. RJR Tobacco Company. November 22, 1985. Bates No: 504978310-8310.

25 Albert MA. Project XG - packaging, tipping, and product qualitative final report. RJR Tobacco Company. November 15, 1985. Bates No: $505278251-8262$

26 RJ Reynolds. ZX task force. RJR Tobacco Company. June 12, 1984 Bates No: 503715134-5180.

27 RJ Reynolds. International seminar on TSB technology - March 13 1986. RJR Tobacco Company. March 13, 1986. Bates No: 504664431-4520

28 Cox AR, Lees HJ, Nassar SC, et al. Camel franchise supplement to project XG (FFNM) prototype test. RJR Tobacco Company. June 6, 1985. Bates No: $505318189-8190$.

29 Parks HT. Project XG - product development. RJR Tobacco Company April 24, 1985. Bates No: 504406225-6226

30 Line WB. Carbowax - how it improves cigarette taste. RJR Tobacco Company. August 11, 1990. Bates No: 508362459-2460.

31 RJ Reynolds. G13-23 proposal. RJR Tobacco Company. 1984. Bates No: $505165290-5302$

32 Vuksan KW, Guess HE, Blackmer EM, et al. Camel Filter Improved Product. RJR Tobacco Company. November 9, 1989. Bates No: 507228566-8566

33 RJ Reynolds. Camel strategic product development plan. RJR Tobacco Company. September 1989. Bates No: 507277978-7982.

34 RJ Reynolds. Camel Lights 85 improved product testing. RJR Tobacco Company. January 23, 1989. Bates No: 507023736-3766.

35 RJ Reynolds. Product sevelopment. RJR Tobacco Company. May 16, 1989. Bates No: 507066407-6412.

36 Bates LE. Camel Lights franchise test: brand perspective - BRD 91-0002-LEB. RJR Tobacco Company. June 21, 1991. Bates No: 508277284-7285

37 RJ Reynolds. Winston Kings/Camel Filter/Magna Box $83 \mathrm{~mm}$ conversion test (Bid \# 9094109 M/A/R/C\# 146-0205) FF NM 85 Marlboro, Males 18-24. RJR Tobacco Company. April 9, 1990. Bates No: $509119162-9166$

38 RJ Reynolds. Product research proposal (Bid \# 89-) Camel Lights $83 \mathrm{~mm}$ box conversion Study. RJR Tobacco Company. April 9, 1990. Bates No: 507307930-7933

39 Pasterczyk RC. Camel FF/LTS 85MM - Box vs. soft pack analysis. RJR Tobacco Company. June 12, 1992. Bates No: 508395915-5934.

40 RJ Reynolds. 1989 strategy. RJR Tobacco Company. May 15, 1989 Bates No: 507135755-5758.

41 RJ Reynolds. Camel FC - total proposition test. December 1987. RJR Tobacco Company. December, 1987. Bates No: $511447365-7410$.

42 RJ Reynolds. Camel QQ A\&A final report. RJR Tobacco Company. November 1991. Bates No: 507643256-3313

43 Smith KW. Technology assessment status update. RJR Tobacco Company. May 29, 1992. Bates No: 512775555-5597.

44 Robinson AL, Dufour WM. Camel RU 83 Box corporate blend program products. RJR Tobacco Company. May 27, 1993. Bates No: $510697488-7498$

45 RJ Reynolds. Product perception trends (perception tracking study). RJR Tobacco Company. 1991. Bates No: 507648130-8133.

46 RJ Reynolds. Camel Filter 85 Product test presentation - Camel Filter sof pack IPT. RJR Tobacco Company. May 1991. Bates No: 509042846-2861.

47 Monda NR. Camel Lights 85 PGT final report. RJR Tobacco Company. July 10, 1990. Bates No: 508393857-3883.

48 RJ Reynolds. Camel Filter 85 product test presentation - Camel Filter soft pack IPT. RJR Tobacco Company. May 1991. Bates No: 509042846-2861.

49 RJ Reynolds. Camel agenda. RJR Tobacco Company. 1990. Bates No: 507489704-9719.

50 Pasterczyk RC. Camel (Ex NF) SOS by age year. RJR Tobacco Company. March 21, 1994. Bates No: 509684799-4803.

51 Centers for Disease Control. Changes in cigarette brand preferences of adolescent smokers - United States, 1989-1993. MMWR Morb Morta Wkly Rep 1994;577-81.

52 US Department of Health and Human Services. Preventing tobacco use among young people. A report of the Surgeon General, 1994. Atlanta, Georgia: Public Health Service, Centers for Disease Control and Prevention, Office on Smoking and Health, 1994. (US Government Printing Office Publication No S/N 017-001-00491-0.)

53 RJ Reynolds. Brand R\&D 1990 - non menthol product development plan (Total Camel and Full Flavor Low Tar). RJR Tobacco Company. April 18, 1990. Bates No: $508238801-8830$. 
54 RJ Reynolds. Project ATF. RJR Tobacco Company. 1986. Bates No: 505939912-9921.

55 Bates LE. Brand R\&D perspective: Camel 91985 Product Results. RJR Tobacco. September 4, 1990. Bates No: 509337380-7385.

56 RJ Reynolds. Project FAT: blind product test (MDD\#87-41 107) Management Summary. RJR Tobacco Company. November 1987. Bates No: 507015630-5631.

57 Willard RL. Memo re: flavoring work on Project XG. RJR Tobacco Company. November 22, 1985. Bates No: $504978310-8310$.

58 Sterling AT. XG FF Box Topline results. RJR Tobacco Company. December 18, 1985. Bates No: 505315826-5827
59 Albert MA. New brands and strategic research report. Project $\mathrm{Xg}$ - Ff $\mathrm{Nm} 80$ Box prototype. RJR Tobacco Company. January 6, 1986. Bates $\mathrm{Nm} 80$ Box prototype. R
No: $505315814-5819$.

60 RJ Reynolds. Camel Filter 85 CT 1582 A/d. RJR Tobacco Company. 1989. Bates No: 507024431-4432.

61 Snyder SL. Product research report. Camel Filter 85 manufacturing confirmation test. RJR Tobacco Company. July 6, 1989. Bates No: $507125442-5449$

62 Federal Trade Commission. Reports presented annually by the Federal Trade Commission to Congress. The most recent report cited: "Tar," nicotine, and carbon monoxide of the smoke of 1206 varieties of domestic cigarettes for the year 1994. Federal Trade Commission, 1997.

\title{
INFORMATION
}

\section{How to access tobacco industry documents}

\begin{abstract}
As a provision of legal settlement agreements, documents introduced through discovery into litigation
$\triangle$ are to be made publicly available by the tobacco industry through physical depositories. These depositories are located in Minneapolis, Minnesota (Philip Morris, RJ Reynolds, Brown \& Williamson/American Tobacco, Lorillard, the Tobacco Institute, and the Council for Tobacco Research) and Guildford, UK (British American Tobacco). Specifically as a result of the 1998 Master Settlement Agreement between 46 states and the tobacco industry, the documents of the Minnesota Depository are to be duplicated online via searchable web sites maintained by each of the companies. The industry hosted websites are directly linked through both http://www.tobaccoarchives.com and http:// www.tobaccoresolution.com.

Additionally, several resources are available that enhance document research substantially, making search and retrieval easier than on the typical industry site. Tobacco Documents Online is available via http://www.tobaccodocuments.org. In January, 2002, the University of California at San Francisco will release the Legacy Tobacco Documents Library. This collection will be available at http:// legacy.library.ucsf.edu.

Both of these sites offer enhanced searching of the industry collections, as well as novel secondary collections developed by tobacco control experts, many of which are fully abstracted. Additionally, both feature enhanced browsing of document collections, session and search tracking, informal "bookmarking" of documents, and downloadable/printable document images in a variety of formats. Also, Tobacco Documents Online hosts a number of email list serves that would be of interest to researchers. For more information, visit http://www.smokescreen.org.

There are many researchers at work presently, examining the tobacco documents. The National Cancer Institute, the American Legacy Foundation, and the American Cancer Society, among others, are funding this work. Contact those already at work to see what additional resources these projects are developing, and what potential for collaboration exists.

A Guide to Administering Tobacco Document Projects will soon be available from the (US) National Cancer Institute. Contact Dr Michele Bloch (blochm@mail.nih.gov) to obtain a copy or for information on the NCI Program Announcement, "Review and Analysis of Tobacco Industry Documents" (http://grants.nih.gov/grants/guide/pa-files/PAR-01-063.html).

For more information see the brief history and overview of the tobacco industry documents previously published: Malone RE, Balbach ED. Tobacco industry documents: treasure trove or quagmire? Tobacco
\end{abstract} Control 2000;9:334-8. 